\title{
Regime shifts, resilience and recovery of a cod stock
}

\author{
Martin Lindegren $^{1, *}$, Rabea Diekmann ${ }^{1,2}$, Christian Möllmann ${ }^{2}$ \\ ${ }^{1}$ National Institute of Aquatic Resources, Technical University of Denmark, Charlottenlund Castle, \\ 2920 Charlottenlund, Denmark
}

${ }^{2}$ Institute for Hydrobiology and Fisheries Science, University of Hamburg, Grosse Elbstrasse 133, 22767 Hamburg, Germany

\begin{abstract}
In the North and Baltic seas Atlantic cod Gadus morhua stocks collapsed as part or one of the major factors inducing large-scale ecosystem regime shifts. Determining the relative contribution of overfishing and climate variability in causing these shifts has proven difficult. While facing similar climatic conditions, the Sound (i.e. a narrow strait located between the North and Baltic seas) differs from its neighbouring areas in the magnitude of fishing pressure as it is subjected to a local trawl fishing ban since 1932. By means of 3 independent multivariate analyses, we investigated the state and development of the Sound ecosystem, specifically testing for the occurrence of regime shifts and their potential drivers. By comparing the ecosystem development of the Sound with the neighbouring North and Baltic seas, we were able to demonstrate the positive effect of the trawl fishing ban on the resilience of the local cod stock to environmental change. The recovery and healthy condition of the Sound cod stock illustrate the need for adaptive marine management strategies that maximize ecosystem resilience.
\end{abstract}

KEY WORDS: Regime shift · Resilience $\cdot$ Ecosystem $\cdot$ Management $\cdot$ Atlantic cod $\cdot$ Gadus morhua The Sound

\section{INTRODUCTION}

Global fish production is under threat from overexploitation and climate change (Jackson et al. 2001, Hutchings \& Reynolds 2004, Brander 2007). Besides causing an elevated risk of stock collapse (i.e. due to direct depletion by fishing), prolonged overfishing reduces the age, size and geographic diversity of fish populations, thereby increasing their vulnerability to climate driven recruitment stress (Brander 2005, Ottersen et al. 2006, Anderson et al. 2008). To achieve sustainability, adaptive marine management strategies that maximize ecosystem resilience (i.e. the ability to withstand and buffer against change, Holling 1973) are needed (Folke et al. 2004, Steele 2004). The consequences of degrading resilience and increasing ecosystem vulnerability is clearly shown by the poor state of the Atlantic cod Gadus morhua, which was once among the commercially most important fish species in the North Atlantic Ocean. Due to the joint effects of overfishing (Myers et al. 1997, Frank et al. 2005) and climate driven declines in productivity (Beaugrand et al. 2003) many of the stocks collapsed without showing signs of recovery (Hutchings \& Reynolds 2004).

In several areas of the North Atlantic Ocean the collapse of cod stocks was part of or one of the major factors inducing large-scale reorganization of ecosystems (Frank et al. 2005, Kirby et al. 2009, Möllmann et al. 2009). These regime shifts are often driven by external forcing, including climate variability, overfishing and eutrophication (Collie et al. 2004). Determining the relative importance of these drivers in causing regime shifts is difficult due to co-occurring and often synergistic effects. The ability to separate these effects is of vital importance in developing ecosystem-based management strategies and achieving sustainable use of fisheries resources in the future (Pikitch et al. 2004, Marasco et al. 2007, Lindegren et al. 2009). 
In concert with large-scale patterns of ecosystem change across the North Atlantic Ocean (Bundy et al. 2009, Drinkwater et al. 2009, Link et al. 2009), simultaneous regime shifts (during the late 1980s) have been demonstrated for the North and Baltic seas (e.g. Beaugrand 2004, Alheit et al. 2005, Weijerman et al. 2005, Kenny et al. 2009, Möllmann et al. 2009). Both regime shifts were, to a large degree, triggered by climatic changes and overfishing with the collapse of the cod stocks being a major component of these ecosystem reorganizations. In the Baltic Sea the latter resulted in a pronounced trophic cascade leading to changes in the lower trophic levels (Österblom et al. 2007, Casini et al. 2008, Möllmann et al. 2008).

The narrow Sound isone of the straits linking the North and Baltic seas (Fig. 1). Though being hydrologically connected to the Baltic Sea by the northward flow of brackish surface water and to the North Sea by the southward flow of high-saline bottom water, the Sound shows marked differences in biotic conditions. These differences are manifested by locally spawning subpopulations of gadoids and flatfishes (Svedäng et al. 2004), similar to sedentary coastal populations found throughout the North Atlantic Ocean (e.g. Godø 1995, Robichaud \& Rose 2004). Although a spill-over effect and an exchange with adjacent populations has not been quantified, the local cod population seems largely self-sustaining (Svedäng et al. 2004), as suggested by demographic differences (Svedäng et al. 2002), genetic studies (Nielsen et al. 2005) and tagging experiments (Pihl \& Ulmestrand

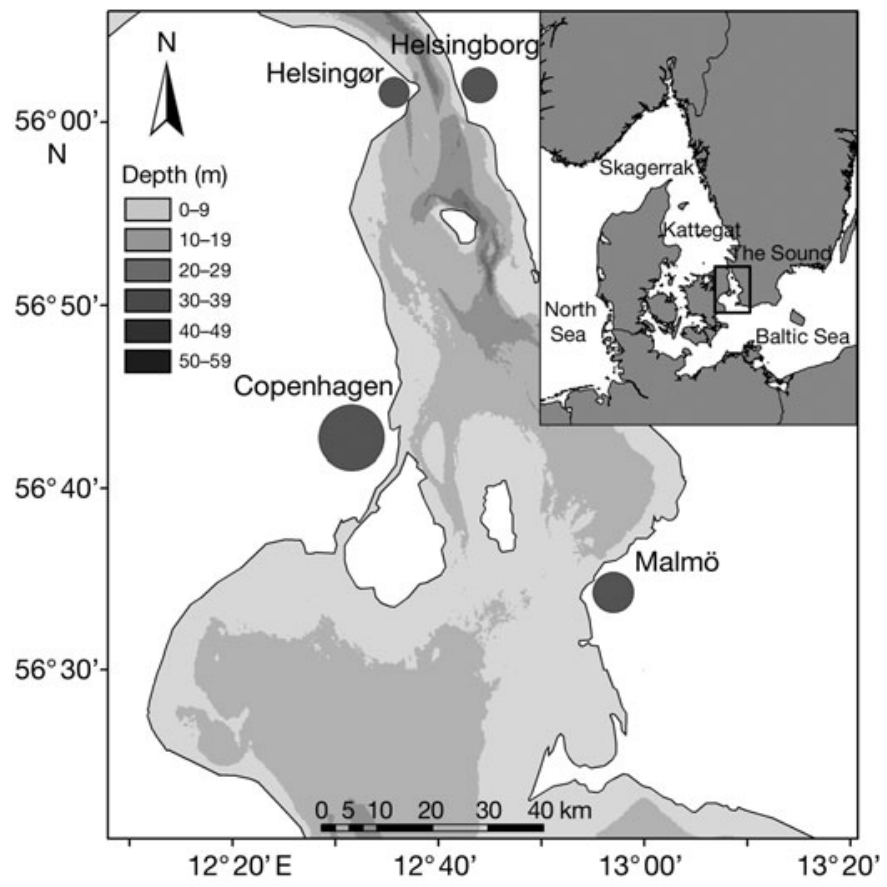

Fig. 1. The Sound (i.e. ICES Subdivision 23) and its position between the North and Baltic seas (inset)
1988, 1993), which points towards reproductive isolation through spawning site fidelity and/or juvenile retention (Robichaud \& Rose 2004, Nielsen et al. 2005). In contrast to the depleted state of neighbouring cod stocks of the North and Baltic seas, the Sound fish stocks in general, and the cod stock in particular, are healthy not only in stock sizes but in the age-size structure of the populations (Svedäng et al. 2002). This difference is attributed to the absence of trawling activities (trawl fishing was banned in 1932 to facilitate shipping, Svedäng et al. 2004). Hence, while facing similar climatic conditions the Sound differs from its neighbouring areas in the magnitude of fishing pressure on the local fish stocks. An investigation of the ecosystem development in the Sound during the last decades and a comparison with the neighbouring North and Baltic seas may help determine the relative importance of the different drivers underlying regime shifts and fish stock collapses in marine ecosystems.

Based on a large multivariate data set we investigated the state and development of the Sound and specifically tested for the occurrence of regime shifts, trophic cascades and their potential drivers. By comparing the ecosystem development in the Sound with the neighbouring North and Baltic seas (i.e. through comparable methods across areas, Megrey et al. 2009) we demonstrated the positive effect of the trawl fishing ban on the resilience of the fish stocks and, in particular, the response of the local cod population to environmental change.

\section{MATERIALS AND METHODS}

Data collection. A data inventory was performed on available time series characterising the Sound ecosystem and its abiotic environment. Selection of variables was based on their ecological importance, the length of the time series and the completeness of the dataset. Furthermore, data collection was restricted to the Sound, excluding the larger western Baltic/Kattegat area, due to (1) data availability, (2) lack of comparable integrated ecosystem analysis in these areas, (3) a primary interest in studying an area that has experienced limited effects from a fishery. In total, 74 biotic and abiotic time series from 1970 to 2006 were compiled. Due to cross-correlations between variables and missing values at the beginning of the investigated period 48 datasets were used for subsequent analyses (Table 1), which covered a period from 1979 to 2005.

To reflect the abiotic environment variables representing both physical oceanographic and nutrient conditions were assembled. Spring and summer values of temperature and salinity were included, which covered the main seasons for primary and secondary 

detailed description and data requests, please contact the ICES/HELCOM Working Group on Integrated Assessments of the Baltic Sea (WGIAB) or the corresponding author. For abbreviations see 'Materials and methods: Data collection'

\begin{tabular}{|c|c|c|c|c|}
\hline Variable & Abbreviation & Season & Unit & Source \\
\hline Surface salinity & $\mathrm{H} 1$ & Spring & psu & DMU/SMHI \\
\hline Surface salinity & $\mathrm{H} 2$ & Summer & psu & DMU/SMHI \\
\hline Bottom salinity & H3 & Spring & psu & DMU/SMHI \\
\hline Bottom salinity & $\mathrm{H} 4$ & Summer & psu & DMU/SMHI \\
\hline Surface temperature & H5 & Spring & ${ }^{\circ} \mathrm{C}$ & DMU/SMHI \\
\hline Surface temperature & $\mathrm{H} 6$ & Summer & ${ }^{\circ} \mathrm{C}$ & DMU/SMHI \\
\hline Bottom temperature & $\mathrm{H7}$ & Spring & ${ }^{\circ} \mathrm{C}$ & DMU/SMHI \\
\hline Bottom temperature & H8 & Summer & ${ }^{\circ} \mathrm{C}$ & DMU/SMHI \\
\hline Baltic Sea Index & H9 & Winter & & IFM \\
\hline Volume outflow & H10 & Annual & $\mathrm{km}^{3}$ & SMHI \\
\hline Volume inflow & H11 & Annual & $\mathrm{km}^{3}$ & SMHI \\
\hline Bottom oxygen & N1 & Spring & $\mathrm{ml} \mathrm{l}^{-1}$ & DMU/SMHI \\
\hline Nitrate & N2 & Winter & $\mu \mathrm{mol} \mathrm{l}^{-1}$ & DMU/SMHI \\
\hline Ammonium & N3 & Winter & $\mu \mathrm{mol} \mathrm{l}^{-1}$ & DMU/SMHI \\
\hline Silica & N4 & Winter & $\mu \mathrm{mol} \mathrm{l} \mathrm{l}^{-1}$ & DMU/SMHI \\
\hline Total phosphorus & N5 & Winter & $\mu \mathrm{mol} \mathrm{l} \mathrm{l}^{-1}$ & DMU/SMHI \\
\hline Chl a & $\mathrm{P} 1$ & Summer & $\mu g \mathrm{l}^{-1}$ & DMU \\
\hline Diatoms & P2 & Spring & $\mu g \mathrm{Cl}^{-1}$ & DMU \\
\hline Dinoflagellates & P3 & Spring & $\mu g \mathrm{Cl}^{-1}$ & DMU \\
\hline Cryptophyceans & $\mathrm{P} 4$ & Spring & $\mu g \mathrm{Cl}^{-1}$ & DMU \\
\hline Nanoplankton & P5 & Spring & $\mu g \mathrm{Cl}^{-1}$ & DMU \\
\hline Dinoflagellates & P7 & Summer & $\mu \mathrm{g} \mathrm{C} 1^{-1}$ & DMU \\
\hline Cryptophyceans & P8 & Summer & $\mu \mathrm{g} \mathrm{C}{ }^{-1}$ & DMU \\
\hline Nanoplankton & P9 & Summer & $\mu \mathrm{g} \mathrm{C}{ }^{-1}$ & DMU \\
\hline Cyanobacteria & P10 & Summer & $\mu g \mathrm{C}^{-1}$ & DMU \\
\hline $\begin{array}{l}\text { Flagellates } \\
\text { (microzooplankton) }\end{array}$ & M1 & Spring & $\mu \mathrm{g} \mathrm{C} 1^{-1}$ & DMU \\
\hline Other microzooplankton & M2 & Spring & $\mu g \mathrm{Cl}^{-1}$ & DMU \\
\hline $\begin{array}{l}\text { Flagellates } \\
\text { (microzooplankton) }\end{array}$ & M3 & Summer & $\mu \mathrm{g} \mathrm{C} 1^{-1}$ & DMU \\
\hline Other microzooplankton & M4 & Summer & $\mu g \mathrm{Cl}^{-1}$ & DMU \\
\hline Acartia spp. & Z1 & Summer & $\mu g \mathrm{Cl}^{-1}$ & DMU \\
\hline Centropages spp. & $\mathrm{Z} 2$ & Summer & $\mu g \mathrm{C}^{-1}$ & DMU \\
\hline Pseudocalanus spp. & $\mathrm{Z} 3$ & Summer & $\mu g \mathrm{Cl}^{-1}$ & DMU \\
\hline Temora longicornis & $\mathrm{Z} 4$ & Summer & $\mu \mathrm{g} \mathrm{C} 1^{-1}$ & DMU \\
\hline Evadne spp. & Z5 & Summer & $\mu \mathrm{g} \mathrm{C} 1^{-1}$ & DMU \\
\hline Oithona similis & Z6 & Summer & $\mu \mathrm{g} \mathrm{C} 1^{-1}$ & DMU \\
\hline Podon spp. & $\mathrm{Z7}$ & Summer & $\mu \mathrm{g} \mathrm{C} 1^{-1}$ & DMU \\
\hline Bosmina spp. & Z8 & Summer & $\mu \mathrm{g} \mathrm{C} 1^{-1}$ & DMU \\
\hline Crustaceans & B1 & Annual & $\mathrm{g} \mathrm{m}^{-2}$ & DMU \\
\hline Echinoderms & B2 & Annual & $\mathrm{g} \mathrm{m}^{-2}$ & DMU \\
\hline Molluscs & B3 & Annual & $\mathrm{g} \mathrm{m}^{-2}$ & DMU \\
\hline Polychaetes & B4 & Annual & $\mathrm{g} \mathrm{m}^{-2}$ & DMU \\
\hline Whiting landings & $\mathrm{F} 1$ & Annual & t $\mathrm{yr}^{-1}$ & FD \\
\hline Dab landings & $\mathrm{F} 2$ & Annual & $\mathrm{tyr}^{-1}$ & FD \\
\hline Plaice landings & F3 & Annual & $\mathrm{tyr}^{-1}$ & FD \\
\hline Flounder landings & $\mathrm{F} 4$ & Annual & $\mathrm{t} \mathrm{yr}^{-1}$ & FD \\
\hline Cod landings & F5 & Annual & $\mathrm{tyr}^{-1}$ & FD \\
\hline Herring landings & F6 & Annual & $\mathrm{t} \mathrm{yr}^{-1}$ & FD \\
\hline
\end{tabular}

Table 1. Description of time series used in multivariate analysis. For a more

included to represent the hydrodynamics of the area. Furthermore, the Baltic Sea Index (BSI), which reflects the effect of climate variability on oceanographic processes in the area (Lehmann et al. 2002), was included. Oxygen conditions were represented by bottom concentrations during spring and nutrient conditions by winter concentrations of nitrate, ammonium, silica and total phosphorus.

The selected biotic variables cover all trophic levels from primary producers to top-predatory fish. Summer chlorophyll a (chl a) was used as a proxy for total phytoplankton biomass. To account for changes in the relative taxonomic composition of the phytoplankton groups during spring and summer the biomass of diatoms, dinoflagellates, cryptophyceans, nanoplankton and cyanobacteria (summer) were used in the analysis. The zooplankton community is represented by summer biomass values of copepods (Acartia spp., Centropages spp., Pseudocalanus spp. and Temora longicornis) and cladocerans (Evadne spp., Oithona similis, Podon spp. and Bosmina spp.). Benthos is characterised by annual biomass averages of molluscs, polychaetes, echinoderms and crustaceans. Annual landings from the local gill net fishery of the commercially most important fish species Atlantic cod, whiting Merlangius merlangus, Atlantic herring Clupea harengus, plaice Pleuronectes platessa, flounder Platichthys flesus and dab Limanda limanda were chosen to characterise the fish community. Landings of seasonally occurring species such as garfish Belone belone, Atlantic mackerel Scomber scombrus and European eel Anguilla anguilla were excluded. However, herring landings consisting of both a local population and the Rügen spring-spawning herring were inproduction as well as the relevant periods for fish reproduction. Due to a strong and permanent stratification, both surface and bottom values were used. Total annual inflow (southward) and outflow (northward) of water through the Sound, which accounts for only a fraction of the total water flux between the North and Baltic seas (Fischer \& Matthäus 1996), were cluded since it resides in the Sound during a major part of the year from August to March (Nielsen et al. 2001).

Environmental and biological data were extracted from published reports and the databases hosted by The Danish National Environmental Research Institute (DMU) (www.dmu.dk) and the Swedish Meteorological and Hydrological Institute (SMHI) (www.smhi.se). Fish 
survey data were extracted from International Council for the Exploration of the Sea (ICES) database (www. ices.dk) and commercial landings from The Danish Directorate of Fisheries (FD) (www.fd.dk) and the Swedish Board of Fisheries (www.fiskeriverket.se).

Regime shift analysis. Principal component analysis (PCA) was used to extract the most important modes of variability in the time series. Beforehand, we replaced missing values in the dataset by variable averages. To improve linearity between variables and to reduce the relationship between the mean and the variance, all biological variables were $\ln (x+1)$ transformed. Our analyses included a PCA using all 48 time series, followed by 2 separate PCAs for either abiotic (16 series) or biotic variables (32 series). All 3 PCAs were conducted based on the correlation matrix and the first factorial plane was visualised as a correlation biplot.

To identify potential regimes in the data sets chronological clustering was performed to objectively identify the years where the largest shifts occurred. This method describes discontinuities in a multivariate series of samples and takes into account the sequence of sampling, which makes it possible to eliminate singletons (Legendre et al. 1985, Legendre \& Legendre 1998). To show the most important breakpoints in the dataset, the significance level alpha, which can be considered as clustering intensity parameter, was set to 0.01 and the connectedness level to $50 \%$. Corresponding to the methodological approach used in the PCA data were first standardised and then the Euclidean distance function was calculated to determine the similarity between years.

In a further analysis we applied the sequential $t$-test analysis of regime shifts (STARS) method (Rodionov 2004) to normalized averages (e.g. Hare \& Mantua 2000) of hydrographic and nutrient time series as well as for each functional group, i.e. phytoplankton, zooplankton, benthos and fish separately. The STARS algorithm is designed to detect statistically significant shifts in the mean level and the magnitude of fluctuations in time series by using modified 2-sided Student's $t$-tests. STARS can detect shifts at different time scales and magnitudes by varying the probability level of the tests and the cut-off length that controls the duration of regimes (Rodionov \& Overland 2005). In the present study we applied a significance level of $p=0.05$ and $a$ cut-off length of $10 \mathrm{yr}$. More information on the STARS method and Excel add-in software is available online at www.beringclimate.noaa.gov.

Trophic cascade analysis. Trophic cascades are defined by alternating top-down and bottom-up regulation and the propagation of indirect positive feedbacks between nonadjacent trophic levels (Pace et al. 1999, Casini et al. 2008). To first provide an understanding of the underlying processes of ecosystem regulation in the
Sound we investigated the potential occurrence of trophic cascades by applying a simple linear regression analysis on selected time series representing key components of the different trophic levels of the ecosystem. In addition, a regression analysis on aggregated biomasses for each trophic level was performed. All time series were $\log$ transformed to stabilise the variance. Model diagnostics were applied to test for the assumption of normality and independence of residuals.

Cross-ecosystem comparisons. For the cross-ecosystem comparison, principle component 1 (PC1) scores from regime shift studies in the North Sea (Weijerman et al. 2005) and the central Baltic Sea (Möllmann et al. 2009) were collected (i.e. chosen to cover the whole period from 1979 to 2005). PC1 can be considered as an integrated indicator of ecosystem state and development (Möllmann et al. 2009). The STARS method was then applied to the PC1 scores, including the Sound, to compare the timing and magnitude of the regime shifts. We also compared the spawning stock biomass (SSB), i.e. derived from standard stock assessments in the North and Baltic seas, and landings of the cod and the dominant pelagic fish stock between areas. Since landings may not accurately reflect the true stock dynamics in the Sound, we additionally collected independent survey data and catch per unit effort (CPUE) estimates (landings per trawling hour) available for cod from 1991 to 2006 and 1996 to 2006, respectively. All statistical analyses were conducted with the Brodgar (www.brodgar.com) and R software (www.r-project.org).

\section{RESULTS}

\section{Ecosystem analysis}

The PCA of the full data set, which takes into account both abiotic and biotic variables, resulted in $35.6 \%$ explained variance on the first 2 PCs (a plot of eigenvalues for each principle component of the 3 PCAs is shown in Fig. S1 in the supplement available at www.int-res.com/articles/suppl/m402p239_app.pdf). Scores along the first PC $(24.2 \%)$ showed a clear temporal trend from positive values in the early years and negative values from the 1990s onwards separated by a sharp decrease in scores between 1987 and 1988

Fig. 2. Year scores at the first 2 axes (PC1 [solid] and PC2 [dotted]) resulting from the principle component analysis (PCA) of (A) full, (C) abiotic and (E) biotic dataset. Vertical lines indicate the time of the most important breakpoints obtained from chronological clustering using an alpha value of 0.01. ( $\mathrm{B}, \mathrm{D}, \mathrm{F})$ Correlation biplots from each normalised PCA. The angles between eigenvectors represent the degree of correlation between variables (see Table 1) and PC axes 

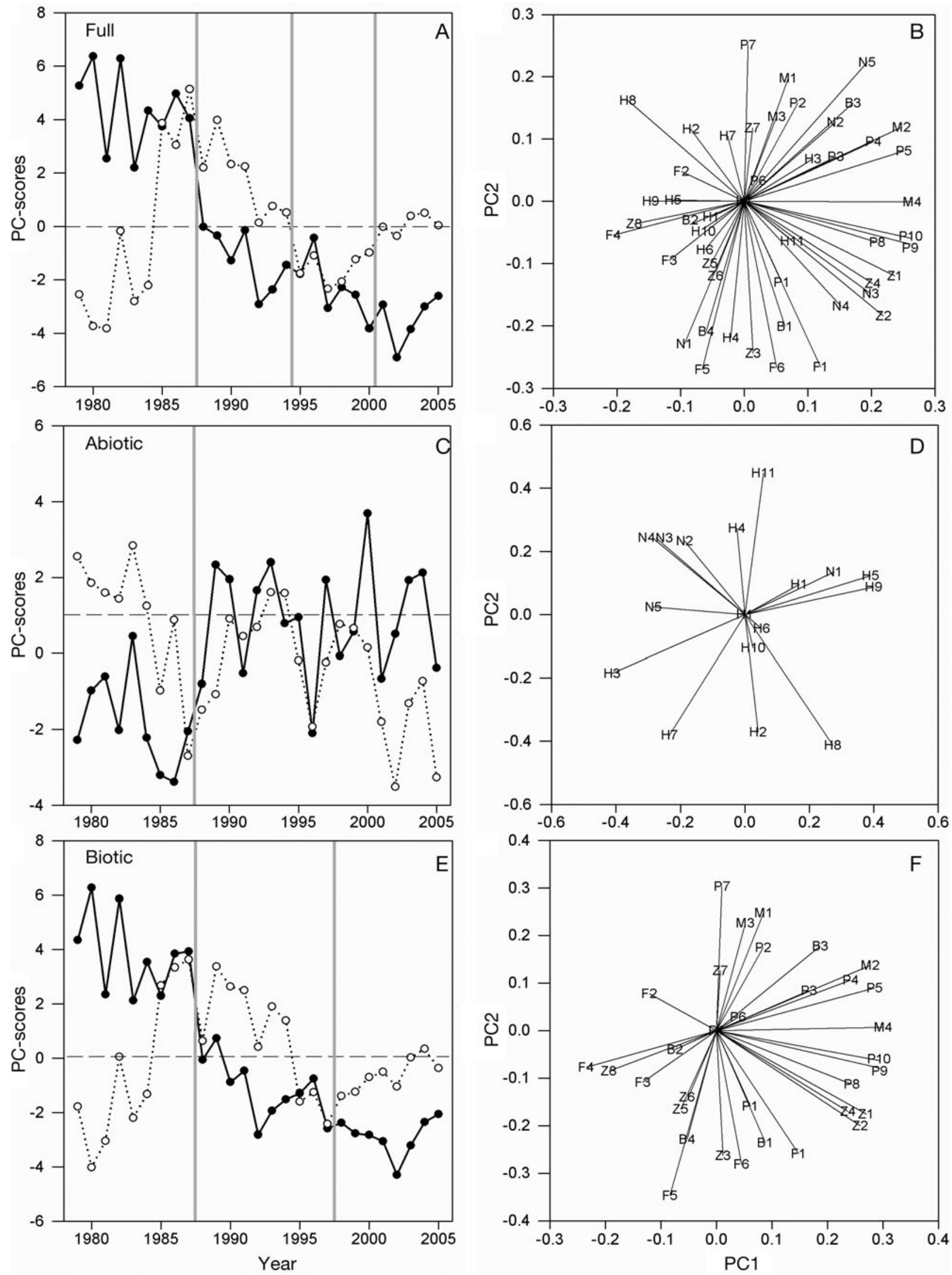
(Fig. 2A). The variable loadings, i.e. the length and orientation of vectors on the correlation biplot, visualise the degree of correlation with the respective PC (Fig. 2B). Thus, nutrients (N2, N5), small-sized phytoplankton (P4, P5, P8, P9), cyanobacteria (P10), copepods (Z1, Z2, Z4), microzooplankton (M4) and molluscs (B3) were mainly positively correlated to PC1, while flatfish (F2 to F4), Bosmina spp. (Z8) and summer bottom temperatures (H8) showed negative correlations. The negative correlation thus indicates an increasing trend in each of these variables within the last $15 \mathrm{yr}$, e.g. higher flatfish landings. The second PC (11.4\%) showed an initial sharp increase in scores followed by a gradual decrease and a rather stable period in the last 10 yr. Large-sized phytoplankton (P2, P7) and microzooplankton (M1, M3) showed positive correlations to this axis, while landings of herring (F6), cod (F5) and whiting (F1) and biomass of Pseudocalanus spp. (Z3) were negatively correlated with PC2. This means that these variables generally increased since the mid-1990s. Finally, the outflow (H10) and inflow (H11) did not explain much of the variation on the first 2 PCs (Fig. 2B), indicating that transport and advection, no matter how important for the physical environment (Fig. 2C), seem to be uncorrelated to the temporal dynamics of most ecosystem components.

The second PCA, using only abiotic time series, explained $39.2 \%$ of the variance on the first factorial plane. PC1 scores $(21.5 \%)$ showed strong fluctuations with an overall increasing trend since the late 1980s (Fig. 2C). In the correlation biplot (Fig. 2D), BSI (H9) and spring surface temperature (H5) were positively correlated to $\mathrm{PC} 1$, indicating their overall increase during the last decades. In contrast, spring bottom salinity (H3) and nutrient conditions (N2 to N5) decreased and showed negative correlations to the first axis. PC2 scores $(17.7 \%)$ oscillated with high values at the beginning and low values at the end of the investigated period. Volume inflow (H11) and summer bottom salinity (H4) showed positive correlations, while bottom temperatures $(\mathrm{H} 7, \mathrm{H} 8)$ and surface salinity $(\mathrm{H} 2)$ showed negative correlations to PC2.

The third PCA, which used only biological time series, explained $41.3 \%$ of the variance on the first factorial plane. The temporal development of PC1 and PC2 scores (Fig. 2E) were relatively similar to the results of the first PCA that used the full data set (Fig. 2A). During the first years PC1 scores $(28.3 \%)$ showed positive values, but shifted to negative values following a sharp decrease from 1987 to 1988 (Fig. 2E). The eigenvectors (Fig. 2F) of small-sized phytoplankton (P4, P5, P9), cyanobacteria (P10), microzooplankton (M2, M4), copepods (Z1, Z2, Z4) and molluscs (B3) were positively correlated to $\mathrm{PC} 1$, while landings of flatfish (F3, F4) and biomass of Bosmina spp. (Z8) showed negative correlations. PC2 scores (13.1\%) showed an increasing trend until 1991, followed by a gradual decrease and a more stable period with negative values occurring in recent years. Dinoflagellates (P7), diatoms (P2) and microzooplankton (M1, M3) showed positive correlations to this axis, while landings of herring (F6), cod (F5) and whiting (F1) and biomass of Pseudocalanus spp. (Z3) were negatively correlated, thus indicating comparatively high values during the last $10 \mathrm{yr}$.

The vertical lines superimposed on the PCA plots (Fig. 2) show the most important breakpoints identified by chronological clustering using an alpha value of 0.01. In all 3 data sets, i.e. the full (Fig. 2A), abiotic (Fig. 2C) and biotic data set (Fig. 2E), respectively, significant breakpoints were detected from 1987 to 1988. Furthermore, 2 breakpoints were identified in the full data set from 1994 to 1995 and 2000 to 2001 (Fig. 2A) and in the biotic data set from 1997 to 1998.

The STARS method identified significant regime shifts that largely coincided with the breakpoints detected by chronological clustering. The hydrographic data (Fig. 3A) showed a clear regime shift from 1987 to 1988 , corresponding to a dramatic shift mainly in bottom salinity, SST and BSI. The increase and decrease in the mid-1990s were not identified as separate states. Due to a sharp decrease in nitrogen and phosphorus, the nutrient data (Fig. 3B) showed 2 regime shifts from 1987 to 1988 and 2001 to 2002, respectively. Coinciding with the decrease in nutrients, primary producers (Fig. 3C) also demonstrated a shift from 1987 to 1988. Zooplankton showed a regime shift from 1988 to 1989, which thus lagged by 1 yr compared with the 1987 to 1988 regime shifts. The sharp increase from 1994 to 1995 and the consecutive period of high values were due to its short duration, and was not identified as a separate regime (Fig. 3D). Benthos data (Fig. 3E) showed one significant shift from 1991 to 1992, which was delayed in comparison with the previously mentioned groups. As in all other groups, the fish data showed a sharp decrease since the mid-1980s (Fig. 3F). Though showing 2 consecutive declines from 1985 to 1987 and 1989 to 1991 , respectively, only the first shift was found to be significant. Additionally, an opposite shift was observed from 1996 to 1997, possibly following the sharp decrease in the hydrography and increase in zooplankton variables from 1994 to 1995.

Fig. 3. Regime shifts in climate, nutrient and biological time series: (A) climate, (B) nutrient, (C) primary producers, (D) zooplankton, (E) benthos, (F) fish. Variables of each group are standardised to zero mean and unit variance and reverted such that the steps show the same sign in all time series. Significant stepwise shifts in means (black line) were detected using significance level $p=0.05$ and a cut-off length of $10 \mathrm{yr}$ 

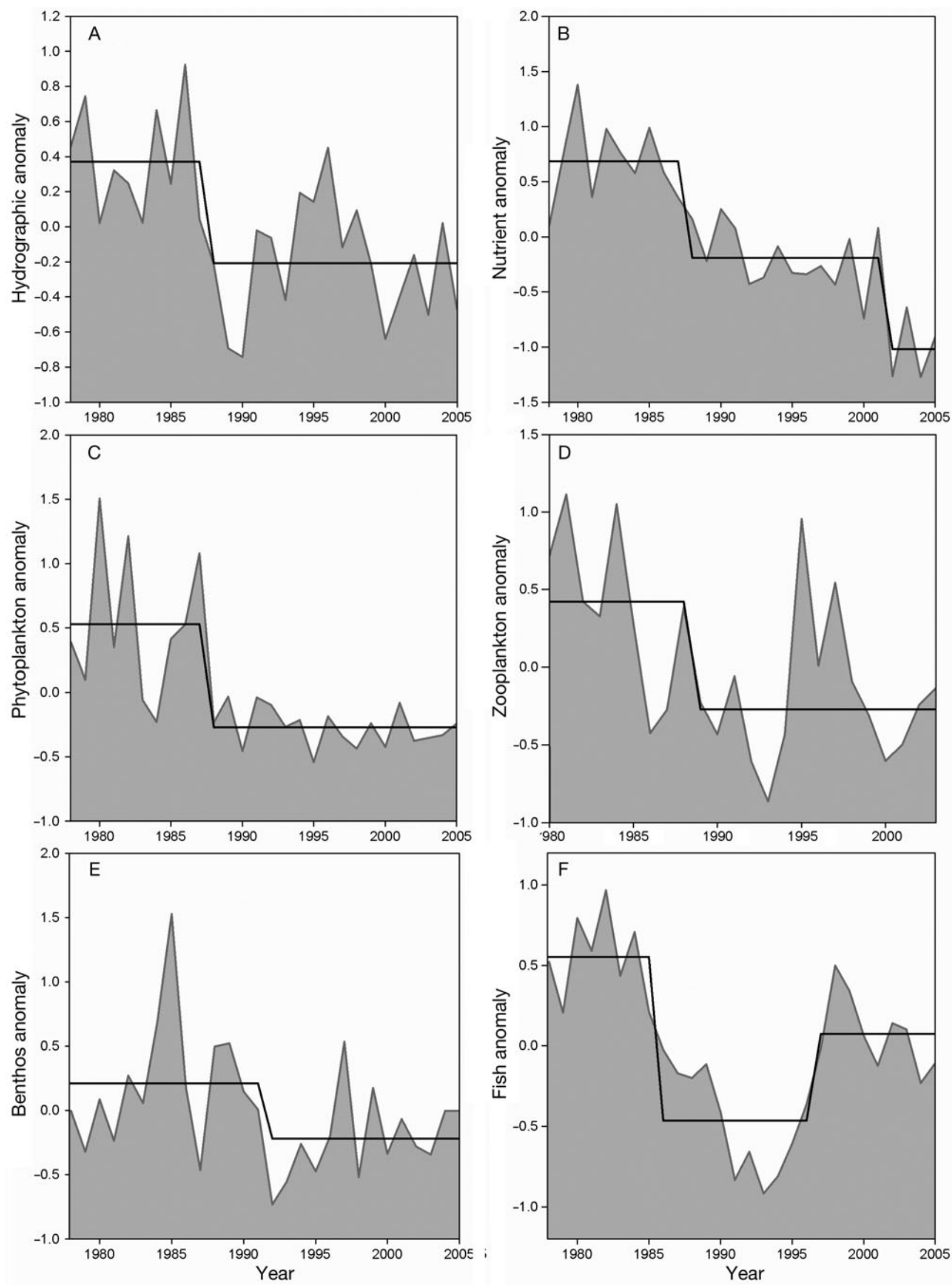


\section{Trophic cascade analysis}

To visualise top-down and bottom-up regulation in the Sound, selected time series from each functional group were graphically displayed as standardised anomalies (Fig. 4). Based on the similarities in temporal dynamics of the selected variables, the analysis suggests 2 parallel pathways of bottom-up regulation in the Sound, the first linking hydrographic-climatic processes to zooplankton and fish and the second linking nutrient dynamics to primary producers and benthos. The first pathway is clearly visible in the relationships between bottom salinity, Pseudocalanus spp., herring and cod (Fig. 4A, C,E). The variables were chosen as they represent key hydrographic variables and the dominant zooplankton and fish species in the area. The second pathway is visualised by the similar temporal dynamics of winter concentration of phosphorus (considered to be the limiting nutrient in the area, Wasmund \& Uhlig 2003), total photosynthetic biomass and mollusc biomass, the latter representing the most abundant benthic group in the Sound. A regression analysis on the selected time series showed a highly significant and positive relationship between each trophic level (Table 2), i.e. between zooplankton (Pseudocalanus spp.), planktivorous fish (herring) and piscivorous fish (cod) as well as between primary producers and benthos (molluscs). Furthermore, these patterns are consistent when also considering aggregated biomasses for each trophic level (Table 3).This indicates strong bottomup regulation in all parts of the ecosystem and rules out the possibility of trophic cascades, since trophic cascades are generally identified by inverse (negative) relationships between adjacent trophic levels (Pauly et al. 1998, Worm \& Myers 2003, Casini et al. 2008).

\section{Cross-ecosystem comparisons}

As illustrated by the generally declining PC1 scores from the North Sea (Fig. 5A), the Sound (Fig. 5C) and the central Baltic Sea (Fig. 5E), the areas show similar ecosystem dynamics during the observed period. Likewise, the timing and magnitude of regime shifts detected by STARS all coincide during the period from 1987
Fig. 4. Selected time series from each trophic level (i.e. standardised to zero mean and unit variance) visualising the 2 pathways of ecosystem regulation in the Sound. (A) Summer bottom salinity (dotted) and summer biomass of Pseudocalanus spp. (solid). (B) Winter total phosphorus concentrations (dotted) and total phytoplankton biomass (solid). (C) Summer biomass of Pseudocalanus spp. (dotted) and landings of herring (solid). (D) Winter total phosphorus concentrations (dotted) and biomass of molluscs (solid). (E) Landings of herring Clupea harengus (dotted) and cod Gadus morhua (solid). (F) Summer total phytoplankton biomass (dotted) and biomass of molluscs (solid). (A regression analysis of the presented time series is presented in Table 2)

to 1988. The dynamics of cod stocks from the North Sea (Fig. 5B) and central Baltic Sea (Fig. 5F) largely follow the ecosystem developments, while for cod stock in the Sound the initial decrease is followed by an increase since the mid-1990s (Fig. 5C). Since landings data may not adequately describe the cod stock dynamics, we additionally plotted landings data with independent survey data available from 1991 to 2006. The strong correlation with survey data $(r=0.79, \mathrm{p}<$

Table 2. Linear regression analysis on selected time series. Following the 2 suggested pathways of regulation, the analysis is divided into (A) a hydrographicclimatic section and (B) a nutrient section. TP: winter total phosphorus. Model significance via p-values (p), degrees of freedom (df) and regression coefficients, the intercept $a$ and the slope $b$ with associated significance levels $\left({ }^{*} \mathrm{p}<0.05,{ }^{* *} \mathrm{p}<0.01,{ }^{* * *} \mathrm{p}<0.001\right)$ are indicated. To emphasize the type of linear relationship, a positive $(+)$ and negative $(-)$ sign is indicated. The coefficient of determination $\left(\mathrm{R}^{2}\right)$ is shown in percent

\begin{tabular}{|lcccccccc|}
\hline & Predictor & df & $\mathrm{p}$ & $a$ & $b$ & Sign & $\mathrm{R}^{2}$ \\
\hline Response & \multicolumn{2}{c}{ (A) Hydrographic-climatic pathway } & & & & & & \\
$\begin{array}{l}\text { Pseudocalanus spp. } \\
\text { Pseudocalanus spp. }\end{array}$ & Corring & 24 & $<0.001$ & $-6.3^{* * *}$ & $0.50^{* * *}$ & + & 52 \\
Herring & Cod & 24 & 0.007 & $-7.1^{*}$ & $0.58^{* *}$ & + & 23 \\
(B) Nutrient pathway & & & & 0.001 & 0.03 & $1.04^{* * *}$ & + & 37 \\
Total phytoplankton & TP & 24 & $<0.001$ & $7.1^{*}$ & $9.3^{* * *}$ & + & 40 \\
Molluscs & TP & 25 & $<0.001$ & $-3.2^{* * *}$ & $4.0^{* *}$ & + & 62 \\
Total phytoplankton & Molluscs & 24 & 0.008 & $16.3^{* * *}$ & $1.4^{* *}$ & + & 22 \\
\hline
\end{tabular}

Table 3. Linear regression analysis on aggregated biomasses for each trophic level or functional group. Model significance via p-values (p), degrees of freedom (df) and regression coefficients, the intercept $a$ and the slope $b$ with associated significance levels $\left({ }^{*} \mathrm{p}<0.05,{ }^{* *} \mathrm{p}<0.01,{ }^{* * *} \mathrm{p}<0.001\right)$ are indicated. To emphasize the type of linear relationship, a positive (+) and negative $(-)$ sign is indicated. The coefficient of determination $\left(\mathrm{R}^{2}\right)$ is shown in percent

\begin{tabular}{|lccccccc|}
\hline Response & Predictor & df & $\mathrm{p}$ & $a$ & $b$ & Sign & $\mathrm{R}^{2}$ \\
\hline Zooplankton & Climate & 25 & 0.03 & $2.3^{* * *}$ & $0.34^{*}$ & + & 14 \\
Pelagic fish & Zooplankton & 24 & $<0.001$ & $11.3^{* * *}$ & $1.5^{* * *}$ & + & 46 \\
Demersal fish & Pelagic fish & 25 & 0.04 & $11.6^{* * *}$ & $0.2^{*}$ & + & 13 \\
Phytoplankton & Nutrients & 25 & $<0.001$ & $19.8^{* *}$ & $5.2^{* * *}$ & + & 46 \\
Benthos & Phytoplankton & 23 & 0.02 & $3.3^{* * *}$ & $0.05^{*}$ & + & 17 \\
\hline
\end{tabular}



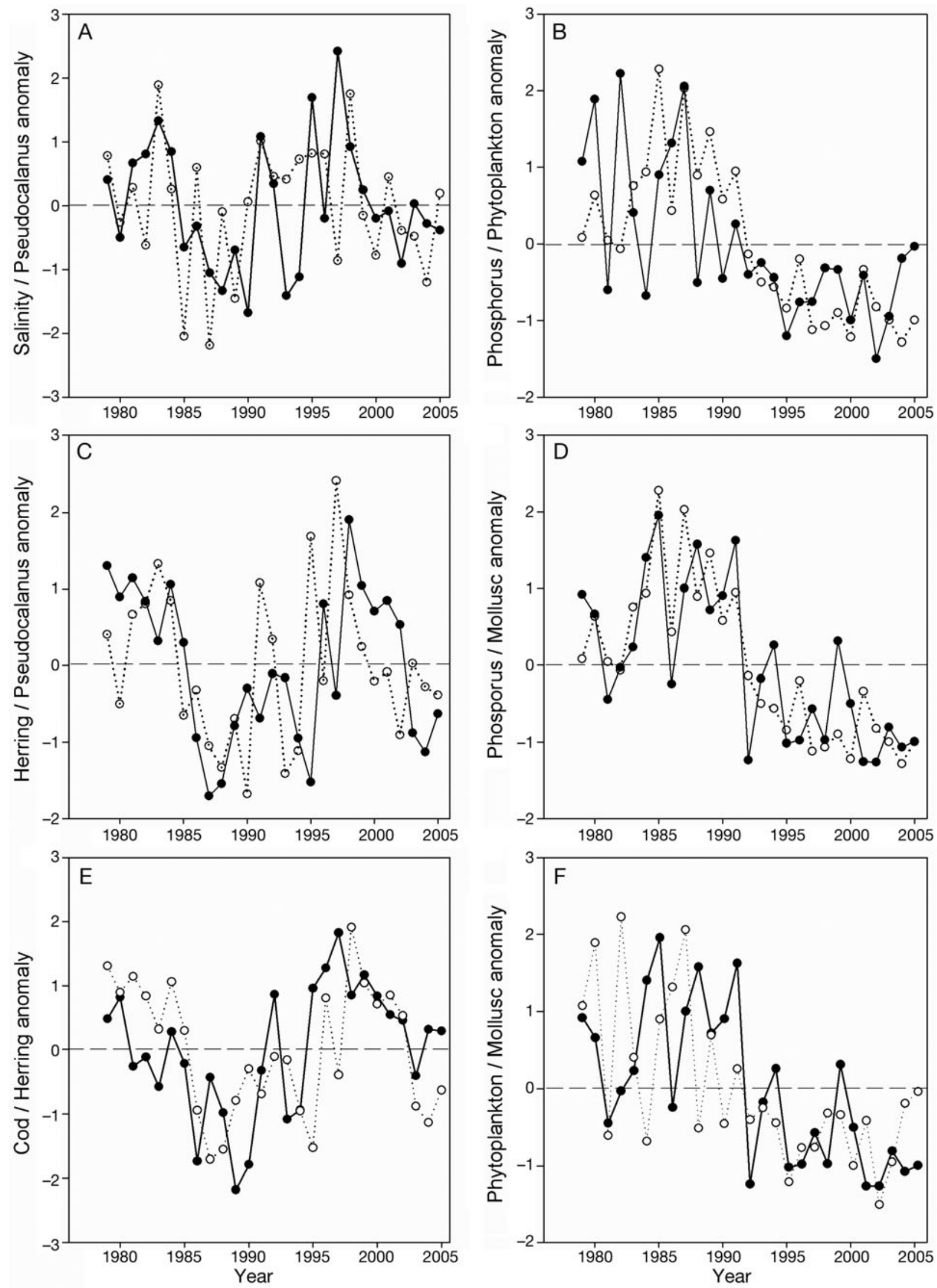

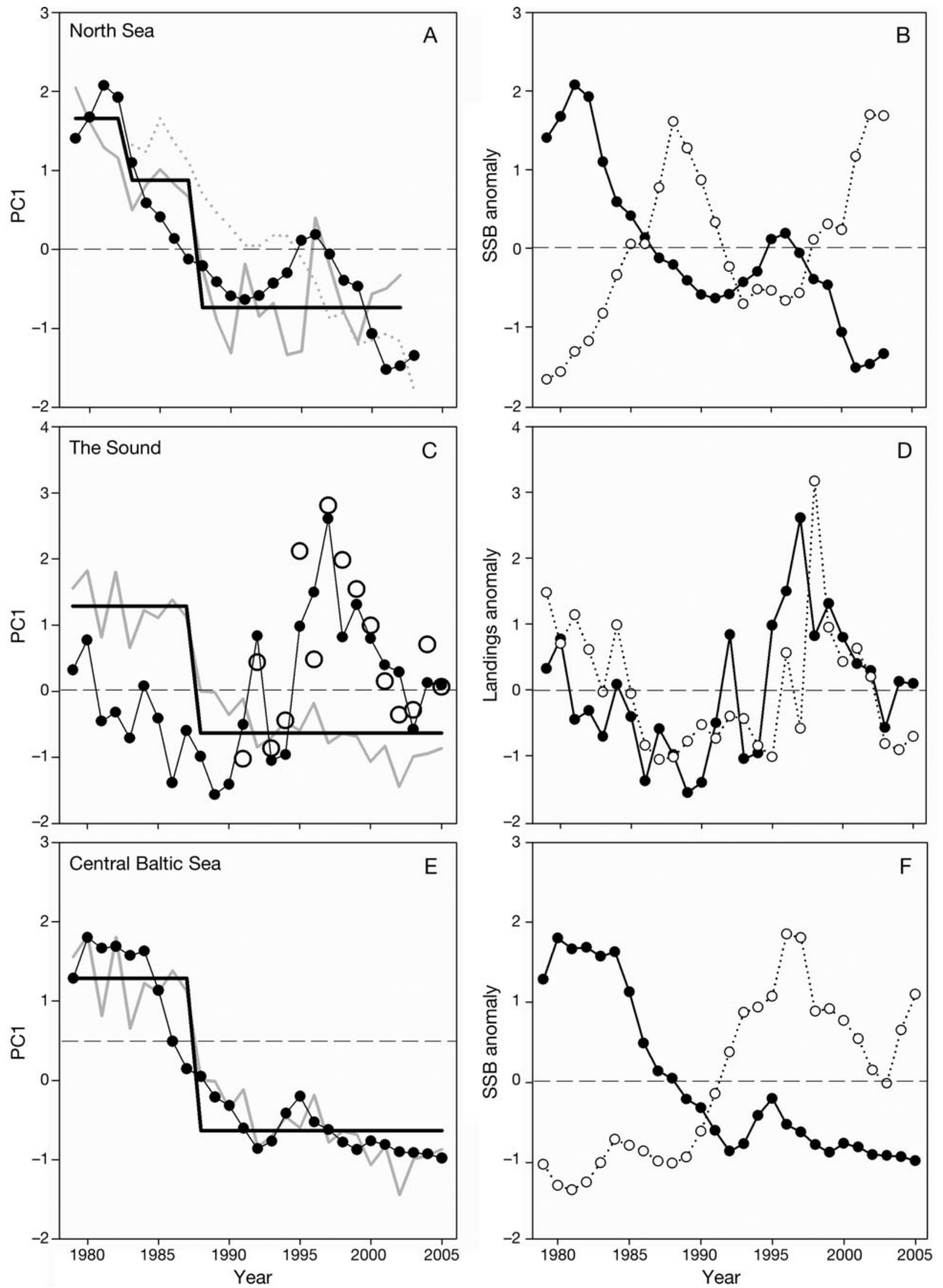
Fig. 5. Comparison of normalised PC1 scores (grey line), spawning stock biomass (SSB) values of cod Gadus morhua (black line) and pelagic fish species (dotted lines) from $(\mathrm{A}, \mathrm{B})$ the North Sea, $(C, D)$ the Sound and $(E, F)$ the central Baltic Sea. Herring Clupea harengus is shown for the North Sea and the Sound, while sprat Sprattus sprattus is shown for the central Baltic Sea. As a complement, PC1 scores from Kenny et al. (2009), which covered a shorter time period between 1983 and 2003, are shown for (A) the North Sea as a dotted grey line. Bold black lines represent the regime shifts as detected by the sequential $t$-test analysis of regime shifts (STARS) method. Cod landings from the Sound are compared with normalised (i.e. to zero mean and unit variance) survey data available from 1991 to 2006 (large circles)

0.001) as well as with CPUE estimates (i.e. landings per trawling hour, $\mathrm{r}=0.82, \mathrm{p}<0.001$ ) indicated that landings may reflect the true stock dynamics, at least from the early 1990s onwards.

In the North and Baltic seas, the regime shift and collapse of the cod stocks triggered a trophic cascade causing changes in the lower trophic levels (Österblom et al. 2007, Casini et al. 2008, Möllmann et al. 2008, Kirby et al. 2009). The trophic cascade is illustrated by the strong negative correlation between cod and sprat Sprattus sprattus $(\mathrm{r}=-0.72, \mathrm{p}<0.001)$, the dominating planktivorous species in the Baltic Sea (Fig. 5F), and between cod and herring $(\mathrm{r}=-0.81, \mathrm{p}<0.001)$, one of the main planktivorous fish species in the North Sea (Fig. 5B). As opposed to the neighbouring areas, the positive relationship between the Sound cod and herring (Table 2) suggests no trophic cascade, but instead a strong bottom-up regulation in the area.

\section{DISCUSSION}

In the North Sea and central Baltic Sea the cod stocks collapsed simultaneously with large-scale ecosystem reorganisations (Reid et al. 2003, Beaugrand 2004, Weijerman et al. 2005, Casini et al. 2008, Möllmann et al. 2008). These regime shifts are considered driven by the combined and synergistic effects of both overfishing and climate variability (Weijerman et al. 2005, Möllmann et al. 2009). Despite the absence of commercial trawl fishing, we also demonstrated a clear shift in the Sound ecosystem. Given the coherent patterns and synchronous timing of regime shifts across the entire North Atlantic Ocean (Bundy et al. 2009, Drinkwater et al. 2009, Link et al. 2009), atmospheric-oceanographic changes are the most likely driver. In the North and Baltic seas, regional climate and hydrographic conditions are mainly influenced by large-scale circulation patterns causing periodic inflow events from the North Atlantic Ocean (Hänninen et al. 2000, Reid et al. 2003). These events affect all parts of the ecosystem from lower trophic levels (Reid et al. 1998, Möllmann et al. 2000, Beaugrand et al. 2003, Wasmund \& Uhlig 2003) to higher trophic levels (Kröncke et al.1998, Möllmann et al. 2003, Durant et al. 2004) and involve a suite of different physical and biological processes, mainly related to effects of temperature, salinity, oxygen, turbulence and advection (Ottersen et al. 2001). In the mid-1980s, the North Atlantic Oscillation (NAO) and BSI shifted sharply from a negative to a positive phase, giving rise to anomalous temperatures, salinities and oxygen conditions throughout the whole area. These climate anomalies, by means of direct and indirect biological feedbacks, most probably induced the simultaneous regime shift observed in the North Sea, central Baltic Sea and the Sound from 1987 to 1988.

Depending on the internal structure and the type of external forcing, ecosystem regime shifts may be classified into 3 qualitatively different types: smooth, abrupt and discontinuous (Collie et al. 2004). While the first two represent generally reversible transitions between alternative ecosystem states, a discontinuous shift involves hysteresis, a process preventing the system from switching back to the previous state even if external conditions are restored (Scheffer et al. 2001). In the North and Baltic seas, the regime shift and collapse of the cod stock resulted in a pronounced trophic cascade leading to changes in the lower trophic levels (Österblom et al. 2007, Casini et al. 2008, Möllmann et al. 2008, Kirby et al. 2009). This internal restructuring of the food web may presently maintain the ecosystem in its currently less desirable ecosystem state by means of negative feedbacks (Bakun 2006, Casini et al. 2009, Möllmann et al. 2009). While the regime shifts of the North and Baltic seas may be described as discontinuous, the Sound regime shift shows no signs of trophic cascade or shift in trophic control (i.e. between topdown and bottom-up regulation) and is, therefore, probably of the abrupt, but still reversible, kind. Given similar external physical forcing, the observed difference between regime shifts in the North Sea, Baltic Sea and the Sound are probably due to a different magnitude of anthropogenic influences, e.g. with respect to eutrophication and fishing pressure, which both affect the internal structure and resilience of the ecosystem.

Eutrophication has caused regime shifts in lakes (Carpenter et al. 1987, Scheffer \& van Nes 2007) and estuarine ecosystems (Daskalov et al. 2007, Hansson et al. 2007, Oguz \& Gilbert 2007, Österblom et al. 2007). The Sound faced severe eutrophication in the early 1980s; however, due to the implementation of efficient waste water treatment, river run-off (mainly of phosphate) was markedly reduced (The Sound Water Cooperation 2004). In combination with limited inflow 
of nutrient-rich bottom water from the North Sea, the nutrient reductions probably caused the strong decline in nutrient conditions during this period. Furthermore, Wasmund \& Uhlig (2003) related decreasing trends in cyanobacteria and chl a to increasing temperatures and a decrease in nutrient loadings, in particular of phosphorus, which is considered a co-limiting nutrient in this area (HELCOM 2002). The shift from smallsized phytoplankton species and N-fixing cyanobacteria to larger-sized diatoms and dinoflagellates in the early 1990s may be explained by a combination of climate changes and nutrient forcing (Wasmund \& Uhlig 2003, Henriksen 2009).

Henriksen et al. (2001) showed significant positive response of macrobenthos abundances to winter nutrient input and spring primary production in Danish waters. Likewise, Kröncke et al. (1998) showed a similar effect on macrozoobenthos in the North Sea. Decreasing nutrient loadings and primary production in combination with a milder climate probably induced the observed changes in the benthic community in the Sound, especially the drastic decrease of filter-feeding molluscs (bivalves). The changes may not be attributed to fishing activities because towed bottom-fishing gear, i.e. trawls, has been banned since 1932. The invasion of the alien polychaete species, Marenzelleria viridis, may further explain the shift in dominance to polychaetes in the early 1990s (Strömberg \& Persson 2005).

Overfishing results in a reduction of the mean age, mean size and geographic diversity of populations and has been shown to increase the sensitivity of fish stocks to climate-driven recruitment stress (Brander 2005, Ottersen et al. 2006, Anderson et al. 2008), thereby impairing their resilience to withstand and buffer against environmental change (Folke et al. 2004). For the North Sea cod, recruitment stress is primarily caused by a temperature driven mismatch in prey availability, which reduces the survival of young cod (Beaugrand et al. 2003); For eastern Baltic cod, low salinities and low oxygen concentrations directly impair recruitment through increased egg and larvae mortalities (Köster et al. 2005). Furthermore, the large sprat stock may impose negative key feedbacks by preying on cod eggs (Köster \& Möllmann 2000) and reducing the main food source of cod larvae, the copepod Pseudocalanus acuspes (Möllmann \& Köster 2002). Though mechanisms are not investigated in detail, our study suggests a positive effect of both bottom salinity and zooplankton availability (i.e. Pseudocalanus spp.) on cod recruitment in the Sound.

Following the regime shift and collapse of the cod stocks in the North and Baltic seas, the populations remained at historically low levels with no or only weak signs of recovery (A slight increase in eastern
Baltic cod has been observed during the recent year). In contrast, the Sound fish stocks in general and the local cod population in particular show a clear recovery in the mid-1990s after the regime shift. The resilience and recovery potential of the cod stock in the Sound is probably due to the absence of commercial trawl fishing, as only local gill net fisheries are allowed in the area (Svedäng et al. 2004). As a consequence, the cod stock shows demographic conditions (age and size distribution) to be far better than the overexploited neighbouring stocks (Svedäng et al. 2002, this paper Fig. S2). With many large, old and experienced individuals and several generations contributing to spawning (Ottersen et al. 2006, Anderson et al. 2008), the cod stock in the Sound seems more resilient to recruitment stress and could therefore recover after experiencing years of potentially unfavourable climate conditions for spawning. Whether the trawling ban increases resilience of the ecosystem by protecting important benthic habitats and organisms, which are vital for growth and recruitment of demersal fish species such as cod (Collie et al. 2000), is presently unclear. To that end, we stress the need for further investigations on the local fish stocks in general, and the cod population in particular, to provide detailed understanding of the mechanisms underlying fish stock resilience in the Sound.

\section{CONCLUSIONS}

Ecosystems worldwide have already shown clear evidence of change in response to changing climate (Walther et al. 2002, Rosenzweig et al. 2008) and even more pronounced alterations might be encountered in the future, especially as climate scenarios predict drastic changes in atmospheric-oceanographic forcing (IPCC 2007). Resilient ecosystems are able to absorb extreme events without changing fundamentally, but if the resilience once is weakened it can be restored only slowly (Folke et al. 2004). Furthermore, hysteresis may even prevent the ecosystem from switching back to the previous state as it is not sufficient to restore external conditions (Scheffer et al. 2001). External conditions can be only partly influenced (e.g. by reducing nutrient loads), but we are able to control fisheries through appropriate and ecologically sound management actions. While the regime shifts in the North and Baltic seas may involve hysteresis, and as such be described as discontinuous, the Sound regime shift shows no signs of trophic cascade or hysteresis and may therefore be of the abrupt but still reversible kind. The present study indicates that low fishing pressure and, hence, healthy fish population sizes and structures can obviously change 
the response of an ecosystem to external forcing. The cod stock in the Sound recovered to preshift conditions whereas those in neighbouring areas remained in a depleted state. The socioeconomic costs of an ecosystem switch with a decline of commercially valuable fish species can be enormous and, therefore, the maintenance and restoration of ecosystem resilience is an important part of a successful ecosystem-based fisheries management strategy (Folke et al. 2004, Marasco et al. 2007).

Acknowledgements. We thank M. Weijermann, A. Kenny, the Danish National Environmental Research Institute, the Swedish Meteorological Institute, the Danish Directorate of Fisheries and the Swedish Board of Fisheries for providing time series and maintaining long-term monitoring and data handling. We also thank a number of anonymous referees for providing valuable input and constructive comments. This research was funded by the EU Marie Curie EST project METAOCEANS (MEST-CT-2005-019678) and is a contribution to the ICES/HELCOM Working Group on Integrated Assessments of the Baltic Sea (WGIAB) and the European Union 6th Framework Projects 'Understanding the mechanisms of stock recovery' (UNCOVER, 022717).

\section{LITERATURE CITED}

Alheit J, Möllmann C, Dutz J, Kornilovs G, Loewe P, Mohrholz V, Wasmund N (2005) Synchronous ecological regime shifts in the central Baltic and the North Sea in the late 1980s. ICES J Mar Sci 62:1205-1215

Anderson CNK, Hsieh CH, Sandin SA, Hewitt R and others (2008) Why fishing magnifies fluctuations in fish abundance. Nature 452:835-839

Bakun A (2006) Wasp-waist populations and marine ecosystem dynamics: navigating the 'predator pit' topographies. Prog Oceanogr 68:271-288

Beaugrand G (2004) The North Sea regime shift: evidence, causes, mechanisms and consequences. Prog Oceanogr 60:245-262

Beaugrand G, Brander KM, Lindley JA, Souissi S, Reid PC (2003) Plankton effect on cod recruitment in the North Sea. Nature 426:661-664

Brander KM (2005) Cod recruitment is strongly affected by climate when stock biomass is low. ICES J Mar Sci 62: 339-343

Brander KM (2007) Global fish production and climate change. Proc Natl Acad Sci USA 104:19709-19714

Bundy AJ, Heymans J, Morissette L, Savenkoff C (2009) Seals, cod and forage fish: a comparative exploration of variations in the theme of stock collapse and ecosystem change in four Northwest Atlantic ecosystems. Prog Oceanogr 81:188-206

Carpenter SR, Kitchell JF, Hodgson JR, Cochran PA and others (1987) Regulation of lake primary productivity by food web structure. Ecology 68:1863-1876

- Casini M, Lövgren J, Hjelm J, Cardinale M, Molinero JC, Kornilovs G (2008) Multi-level trophic cascades in a heavily exploited open marine ecosystem. Proc Biol Sci 275: 1793-1801

Casini M, Hjelm J, Molinero JC, Lövgren J and others (2009) Trophic cascades promote threshold-like shifts in pelagic marine ecosystems. Proc Natl Acad Sci USA 106:197-202
Collie JS, Hall SJ, Kaiser MJ, Poiner IR (2000) A quantitative analysis of fishing impacts on shelf-sea benthos. J Anim Ecol 69:785-798

Collie JS, Richardson K, Steele JH (2004) Regime shifts: Can ecological theory illuminate the mechanisms? Prog Oceanogr 60:281-302

> Daskalov GM, Grishin AN, Rodionov S, Mihneva V (2007) Trophic cascades triggered by overfishing reveal possible mechanisms of ecosystem regime shifts. Proc Natl Acad Sci USA 104:10518-10523

Drinkwater KF, Mueter F, Friedland KD, Taylor M, Hunt J, Hare J, Melle W (2009) Recent climate forcing and physical oceanographic changes in Northern Hemisphere regions: A review and comparison of four marine ecosystems. Prog Oceanogr 81:10-28

> Durant JM, Anker-Nilssen T, Hjermann DO, Stenseth NC (2004) Regime shifts in the breeding of an Atlantic puffin population. Ecol Lett 7:388-394

Fischer H, Matthäus W (1996) The importance of the Drogden Sill in the Sound for major Baltic inflows. J Mar Syst 9: $137-157$

Folke C, Carpenter S, Walker B, Scheffer M, Elmqvist T, Gunderson L, Holling CS (2004) Regime shifts, resilience, and biodiversity in ecosystem management. Annu Rev Ecol Syst 35:557-581

Frank KT, Petrie B, Choi JS, Leggett WC (2005) Trophic cascades in a formerly cod-dominated ecosystem. Science 308:1621-1623

> Godø OR (1995) Transplantation-tagging-experiments in preliminary studies of migration of cod off Norway. ICES J Mar Sci 52:955-962

Hänninen J, Vuorinen I, Hjelt P (2000) Climatic factors in the Atlantic control the oceanographic and ecological changes in the Baltic Sea. Limnol Oceanogr 45:703-710

Hansson S, Hjerne O, Harvey C, Kitchell JF, Cox SP, Essington TE (2007) Managing Baltic Sea fisheries under contrasting production and predation regimes: ecosystem model analyses. Ambio 36:265-271

> Hare SR, Mantua NJ (2000) Empirical evidence for North Pacific regime shifts in 1977 and 1989. Prog Oceanogr 47: 103-145

HELCOM (Helsinki Commission) (2002). Environment of the Baltic Sea area 1994-1998. Baltic Sea Environment Proceedings No. 82B, Helsinki

> Henriksen P (2009) Long-term changes in phytoplankton in the Kattegat, the Belt Sea, the Sound and the western Baltic Sea. J Sea Res 61:114-123

Henriksen P, Andersen J, Carstensen J, Christiansen T and others (2001) Marine områder 2000-Miljøtilstand og udvikling. NOVA 2003. Danmarks Miljøundersøgelser. 110 s. Faglig rapport fra DMU nr. 375, Roskilde

> Holling CS (1973) Resilience and stability of ecological systems. Annu Rev Ecol Syst 4:1-23

Hutchings JA, Reynolds JD (2004) Marine fish population collapses: consequences for recovery and extinction risk. Bioscience 54:297-309

IPCC (Intergovernmental Panel on Climate Change) (2007). Climate change 2007. Synthesis report. Intergovernmental Panel on Climate Change, 4th Assessment Report, Geneva

Jackson JBC, Kirby MX, Berger WH, Bjorndal KA and others (2001) Historical overfishing and the recent collapse of coastal ecosystems. Science 293:629-638

Kenny AJ, Skjoldal HR, Engelhard GH, Kershaw PJ, Reid JB (2009) An integrated approach for assessing the relative significance of human pressures and environmental forcing on the status of large marine ecosystems. Prog Oceanogr 81:132-148 
Kirby RR, Beaugrand G, Lindley JA (2009) Synergistic effects of climate and fishing in a marine ecosystem. Ecosystems 12:548-561

Köster FW, Möllmann C (2000) Egg cannibalism in Baltic sprat Sprattus sprattus. Mar Ecol Prog Ser 196:269-277

Köster FW, Möllmann C, Hinrichsen HH, Wieland K and others (2005) Baltic cod recruitment - the impact of climate variability on key processes. ICES J Mar Sci 62:1408-1425

Kröncke I, Dippner JW, Heyen H, Zeiss B (1998) Long-term changes in macrofaunal communities off Norderney (East Frisia, Germany) in relation to climate variability. Mar Ecol Prog Ser 167:25-36

Legendre P, Legendre L (1998). Numerical ecology, 2nd English edn. Elsevier Science, Amsterdam

> Legendre P, Dallot S, Legendre L (1985) Succession of species within a community-chronological clustering, with applications to marine and fresh-water zooplankton. Am Nat 125:257-288

> Lehmann A, Krauss W, Hinrichsen HH (2002) Effects of remote and local atmospheric forcing on circulation and upwelling in the Baltic Sea. Tellus Ser A Dyn Meteorol Oceanogr 54:299-316

> Lindegren M, Möllmann C, Nielsen A, Stenseth NC (2009) Preventing the collapse of the Baltic cod stock through an ecosystem-based management approach. Proc Natl Acad Sci USA 106:14722-14727

Link JS, Stockhausen WT, Skaret G, Overholtz W and others (2009) A comparison of biological trends from four marine ecosystems: synchronies, differences, and commonalities. Prog Oceanogr 81:29-46

- Marasco RJ, Goodman D, Grimes CB, Lawson PW, Punt AE, Quinn TJ (2007) Ecosystem-based fisheries management: some practical suggestions. Can J Fish Aquat Sci 64: 928-939

Megrey BA, Link JS, Hunt J, Moksness E (2009) Comparative marine ecosystem analysis: applications, opportunities, and lessons learned. Prog Oceanogr 81:2-9

Möllmann C, Köster FW (2002) Population dynamics of calanoid copepods and the implications of their predation by clupeid fish in the Central Baltic Sea. J Plankton Res 24: 959-977

Möllmann C, Kornilovs G, Sidrevics L (2000) Long-term dynamics of main mesozooplankton species in the central Baltic Sea. J Plankton Res 22:2015-2038

Möllmann C, Kornilovs G, Fetter M, Köster FW, Hinrichsen HH (2003) The marine copepod, Pseudocalanus elongatus, as a mediator between climate variability and fisheries in the Central Baltic Sea. Fish Oceanogr 12: 360-368

Möllmann C, Muller-Karulis B, Kornilovs G, St John MA (2008) Effects of climate and overfishing on zooplankton dynamics and ecosystem structure: regime shifts, trophic cascade, and feedback coops in a simple ecosystem. ICES J Mar Sci 65:302-310

- Möllmann C, Diekmann R, Müller-Karulis B, Kornilovs G, Plikshs M, Axe P (2009) Reorganization of a large marine ecosystem due to atmospheric and anthropogenic pressure: a discontinuous regime shift in the Central Baltic Sea. Glob Change Biol 15:1377-1399

Myers RA, Hutchings JA, Barrowman NJ (1997) Why do fish stocks collapse? The example of cod in Atlantic Canada. Ecol Appl 7:91-106

Nielsen JR, Lundgren B, Jensen TF, Staehr KJ (2001) Distribution, density and abundance of the western Baltic herring (Clupea harengus) in the Sound (ICES Subdivision 23) in relation to hydrographical features. Fish Res 50: $235-258$
Nielsen EE, Grønkjaer P, Meldrup D, Paulsen H (2005) Retention of juveniles within a hybrid zone between North Sea and Baltic Sea Atlantic cod (Gadus morhua). Can J Fish Aquat Sci 62:2219-2225

> Oguz T, Gilbert D (2007) Abrupt transitions of the top-down controlled Black Sea pelagic ecosystem during 1960-2000: evidence for regime-shifts under strong fishery exploitation and nutrient enrichment modulated by climate-induced variations. Deep-Sea Res I 54:220-242

Österblom H, Hansson S, Larsson U, Hjerne O, Wulff F, Elmgren R, Folke C (2007) Human-induced trophic cascades and ecological regime shifts in the Baltic Sea. Ecosystems 10:877-889

- Ottersen G, Planque B, Belgrano A, Post E, Reid PC, Stenseth NC (2001) Ecological effects of the North Atlantic Oscillation. Oecologia 128:1-14

Ottersen G, Hjermann DO, Stenseth NC (2006) Changes in spawning stock structure strengthen the link between climate and recruitment in a heavily fished cod (Gadus morhua) stock. Fish Oceanogr 15:230-243

Pace ML, Cole JJ, Carpenter SR, Kitchell JF (1999) Trophic cascades revealed in diverse ecosystems. Trends Ecol Evol 14:483-488

Pauly D, Christensen V, Dalsgaard J, Froese R, Torres F (1998) Fishing down marine food webs. Science 279: 860-863

Pihl L, Ulmestrand M (1988) Kusttorskundersökningar på svenska västkusten. Länsstyrelsen i Göteborgs och Bohus län, Göteborg

> Pihl L, Ulmestrand M (1993) Migration pattern of juvenile cod (Gadus morhua) on the Swedish west coast. ICES J Mar Sci 50:63-70

Pikitch EK, Santora C, Babcock EA, Bakun A and others (2004) Ecosystem-based fishery management. Science 305:346-347

Reid PC, Edwards M, Hunt HG, Warner AJ (1998) Phytoplankton change in the North Atlantic. Nature 391:546

Reid PC, Edwards M, Beaugrand G, Skogen M, Stevens D (2003) Periodic changes in the zooplankton of the North Sea during the twentieth century linked to oceanic inflow. Fish Oceanogr 12:260-269

Robichaud D, Rose GA (2004) Migratory behaviour and range in Atlantic cod: inference from a century of tagging. Fish Fish 5:185-214

> Rodionov SN (2004) A sequential algorithm for testing climate regime shifts. Geophys Res Lett 31:L09204. doi:10.1029/ 2004GL019448

> Rodionov S, Overland JE (2005) Application of a sequential regime shift detection method to the Bering Sea ecosystem. ICES J Mar Sci 62:328-332

Rosenzweig C, Karoly D, Vicarelli M, Neofotis P and others (2008) Attributing physical and biological impacts to anthropogenic climate change. Nature 453:353-357

> Scheffer M, van Nes EH (2007) Shallow lakes theory revisited: various alternative regimes driven by climate, nutrients, depth and lake size. Hydrobiologia 584: 455-466

Scheffer M, Carpenter S, Foley JA, Folke C, Walker B (2001) Catastrophic shifts in ecosystems. Nature 413:591-596

Steele JH (2004) Regime shifts in the ocean: reconciling observations and theory. Prog Oceanogr 60:135-141

Strömberg A, Persson P (2005) Den amerikanska havsborstmasken Marenzelleria viridis längs Helsingborgskusten 2005. Miljönämden i Helsingborg, Helsingborg

Svedäng H, Øresland V, Cardinale M, Hallbäck H, Jakobsson P (2002) De kustnära fiskbeståndens utveckling och nuvarande status vid svenska västkusten. Synopsis av 
'Torskprojektet steg I-III'. Fiskeriverket Informerar (Finfo) 2002:6, Lysekil

Svedäng $\mathrm{H}$, Hagberg $\mathrm{J}$, Börjesson $\mathrm{P}$, Svensson A, Vitale F (2004) Bottenfisk i Västerhavet - Fyra studier av beståndens status, utveckling och lekområden vid den svenska västkusten. Fiskeriverket Informerar (Finfo) 2004:6, Lysekil

The Sound Water Cooperation (2004). The supply of nitrogen and phosphorus to the Sound 2004. Available at www. oresundsvand.dk/reports/BelastningOresund/Belastning 2004.pdf

Editorial responsibility: Jake Rice, Ottawa, Ontario, Canada
Walther GR, Post E, Convey P, Menzel A and others (2002) Ecological responses to recent climate change. Nature 416:389-395

Wasmund N, Uhlig S (2003) Phytoplankton trends in the Baltic Sea. ICES J Mar Sci 60:177-186

Weijerman M, Lindeboom H, Zuur AF (2005) Regime shifts in marine ecosystems of the North Sea and Wadden Sea. Mar Ecol Prog Ser 298:21-39

Worm B, Myers RA (2003) Meta-analysis of cod-shrimp interactions reveals top-down control in oceanic food webs. Ecology 84:162-173

Submitted: October 9, 2009; Accepted: December 7, 2009

Proofs received from author(s): February 23, 2010 